\title{
A BEST POSSIBLE HADAMARD INEQUALITY
}

\author{
A. M. FINK
}

Abstract. The classical Hadamard-Hermite inequality requires that the measure be a symmetric and positive. We prove versions which require neither of these conditions. Furthermore, we prove that no such theorems exist with less restrictions than ours, ie. they are best possible.

Mathematics subject classification (1991): 26D15, 26D20.

Key words and phrases: Hadamard, inequalities, best possible inequalities.

\section{REFERENCES}

[1] L. FEJER, Über die Fouriereichen II, Gesammelte Arbeiten I (German) Budapest (1970), 280-297.

[2] A.M. FinK, Toward a theory of best possible inequalities, Nieuw Archief von Wiskunde 12 (1994), 19-29.

[3] A.M. FinK And Max Jodeit, JR., On Chebyshev's other inequality; Inequalities in Statistics and Probability, (Lecture Notes IMS, No. 5) Inst. Math. Statistics, Haywood, CA (1984), 115-120.

[4] J Jensen inequalities for functions with higher monotonicities, Aeq. Math. 49 (1952), 26-43.

[5] D.S. Mitrinović, J.E. PeČARIĆ, AND A.M. FinK, Classical and New Inequalities in Analysis, Kluwer Academic Publishers, Dordrecht, 1993.

[6] I.J. SchoenBerg, Cardinal spline interpolation, Regional Conference Series in Applied Mathematics \#12, SIAM Philadelphia, 1973. 